This is the accepted manuscript of the article, which has been published in Critical Sociology. 2019, 45(4-5), 683-696.

http://doi.org/10.1177/0896920517740614

Adkins Lisa, Kortesoja Matti, Mannevuo Mona, Ylöstalo Hanna

\title{
Experimenting with Price: Crafting the New Social Contract in Finland
}

\section{Abstract}

This article is concerned with price and pricing in the context of finance led neoliberal reform. It considers the sentiment often encountered in accounts of such reform that price instability is the outcome of the retreat of the state from the regulation of price and its externalization in the competitive play of the market. Drawing on the case of contemporary Finland, and especially a major round of government reform, we show how unstable prices are anchored in a set of co-ordinating mechanisms which form part of the infrastructure of a reorganizing state. We elaborate, then, a state infrastructure for the co-ordination of price instability and do so for the price and pricing of labour. This infrastructure is, however, not one which is coherent, centralised or integrated, but is dispersed and disintegrated and operates on multiple scales.

Keywords: price, neoliberalism, state, wages, workfare, economization

\section{Introduction}

When the current Finnish government started its term in May 2015, the new Prime Minister Juha Sipilä flagged a major programme of reform. We need, he said, 'to all discover the reformer within us'. According to Sipilä, an unusually detailed economic programme was in order because structural reform had been neglected for too long and cuts had become unavoidable (Sipilä, 2015a). To effect such reform the government proposed a Strategic Programme - Finland, a Land of Solutions (Prime Minister's Office, 2015) - which set out austerity as the only way forward. ${ }^{1}$ The government therefore proposed a programme to adjust the economy 'through the reduction of wages, prices and public spending to restore competitiveness' (Blyth, 2013: 2). In so doing the government connected Finland (a member of the European Union since 1995 and the Euro-area since 1999) to the austerity project operating 
across the Eurozone and continued the roll out of the kinds of social, economic and political changes set in play paradigmatically by the UK and the US from the late 1970s onwards.

In this article, we focus on one specific aspect of this reform agenda, namely the price and the pricing of labour. ${ }^{2}$ We pay attention to three dimensions of the government's programme in this regard. First, a social contract, later renamed as a Competitiveness Pact, whose aim is to reduce labour costs by at least 5 per cent; second a business consultant run comprehensive reform of employment services; and third experiments with the unemployed which form part of a consolidation of workfarism in Finland. In so doing we forward an analysis of the dynamics of price and pricing which breaks from the assumption that a neoliberal political and economic environment has amounted to an unleashing of price and pricing from the regulatory mechanisms of the state and their free play in the market. This assumption is commonplace in many accounts of neoliberalism (for example, Bourdieu, 1998; 2003; Chomsky, 1999), and is in play in regard to one of its established features, namely the stagnation of wages (see especially Harvey, 2007; 2010). ${ }^{3}$ Against the view that cuts and downwards pressure on the price of labour (that is, on wages) have been achieved by the cutting loose of wages from regulatory and institutional mechanisms, especially the regulatory instruments of the state, in this article we stress that for the Finnish case such pressure is orchestrated by a dispersed yet enabling infrastructure. We stress that this infrastructure concerns a range of heterogeneous actors which comprise the reformed (and reorganising) state. In forwarding our analysis of what we will characterize here as an organized devaluation of wages we therefore necessarily also confront the reform of the state. Building on and extending existing research on the Finnish state (Ahlqvist and Moisio, 2014; Elomäki et al., 2016; Heiskala and Kantola, 2010; Julkunen, 2013; Kantola and Kananen, 2013; Kettunen, 2008), we suggest that the current round of reform demands greater attention be paid to the process of the economization of the political. That is, we suggest that more attention needs to be focused on the transformation of political into economic authority. This article therefore not only contributes to debates on price and pricing in the context of neoliberal reform but also to debates on the ongoing reform of the Finnish state. ${ }^{4}$ 
In setting out these interventions our theoretical touchstones are threefold. First, analyses which have stressed that the process of neoliberalization does not involve a subordination of the state to the market and/or the capture of the state (and society) by market principles but the activation of the state to generalize the market. While this process was paradigmatically set out by Foucault (2008), of particular relevance to our concerns in this article are analyses which have stressed how this has involved the making and embedding of a set of powerful institutional linkages in which the state plays a powerful role (Humphrys and Cahill, 2017; Konings, 2010; Mirowski and Plehwe, 2009). Second, we draw on analyses which have stressed that rather than necessarily homogenized and centralized these institutional linkages are often dispersed and heterogeneous, indeed that such linkages are often infrastructural in character (Peck and Theodore, 2015). For us what is also significant regarding this emphasis on infrastructure and the infrastructural is that it enables a shift in emphasis away from an overly broad-brush (and ideational) 'neoliberalism' to one focused on the material complexity of institutional linkages (Simone, 2012). Our final touchstone is recent work in political theory and especially Wendy Brown's (2015) analysis of neoliberal rationality which suggests that at stake in the latter is an economization of the political and the inversion of the classic social contract of liberalism. Taken together these resources enable us not only to advance our key intervention - that unstable prices are anchored in a set of co-ordinating mechanisms which form part of the infrastructure of a reorganizing state - but also to propose that confronting unstable prices, and especially the process of the devaluation of the price of labour, is necessarily to confront the turning inside out of the social contract.

To lay out these interventions this article proceeds in four parts. First, we turn to the Finnish government's social contract and attempts at securing its terms. In the second section we outline how the social contract morphed into a Competitiveness Pact whose terms were agreed in 2016. Across these two sections we highlight not only how the terms of the Pact concern cuts to wages but also how these same terms index wages in new ways and do so especially in terms of the multiplier effects of national debt. In the third section, and recognizing that the 
Competitiveness Pact is part of a broader process of reform which includes the on-going reform of the welfare state, we confront a comprehensive restructuring of employment services. We locate this reform as an example of centrally orchestrated devolution which sends large-scale problems, such as unemployment, down the pipeline of power and authority. This prompts us to ask what happens at the end of the pipeline? We address this question in the fourth section which is concerned with experiments with workfare. Here we underscore how such experiments contribute to the organized devaluation of wages via putting in play competition between the employed and unemployed regarding the price of labour. In the conclusion to this article we reflect on how our interventions contribute to debates on the dynamics of price and pricing in the context of neoliberal reform and to understandings of Finnish state restructuring.

The data used to unfold the analysis which follows primarily comprises policy documents (including the government programme itself) as well as recommendations and rules which informed the programme. The latter include European Union country level recommendations, European Monetary Union rules on public deficits and expenditures and the Finnish Ministry of Finance's recommendations regarding budgetary targets and public spending. It also includes consultant and think tank reports. ${ }^{5}$ As we will show these all played decisive roles in the shaping of the programme. This data is supplemented with data from political speeches, news stories, website and blog materials. This material is used to complement the primary data, and especially to assist in contextualizing the programme in the prevailing socio-cultural conditions of contemporary Finland. Our analysis of the primary and secondary data shows that the Finnish state is not a centralised or coherent body populated by homogeneous actors but comprises a set of heterogeneous actors and increasingly comprises economic actors operating on multiple scales. We show, however, that in the current round of reform, and especially in the process of the organized devaluation of the price of labour, fiscal and financial actors are playing a decisive role.

\section{The Price of Labour and the New Social Contract in Finland}


Social contracts have been an integral part of the Finnish labour market policy throughout the $20^{\text {th }}$ century and especially since the late 1960 s. The Finnish industrial relations system can be described as a corporatist regime, characterized by extensive collective bargaining (Kauppinen, 2005). Labour market policies and legislation have been drafted in a tripartite framework between the government, trade unions and employers' organizations. Between 1968 and 2008 the Finnish industrial relations system entailed 'incomes policy agreements' which included centralized bargaining of wage increases as well as social policy and taxation. Even though the last incomes policy agreement was concluded in 2006 , collective agreements continue to play a central role in the Finnish labour market policies and the social partners (trade union confederations and employers' associations) are present in virtually all labour market policy processes. Most Finnish employees are still covered by collective agreements.

In 2015 a newly elected government introduced its own social contract. It was against a background of economic slowdown, rising public debt, increasing unemployment and intensifying surveillance of public deficits in the Euro area that the new government won office. The Centre Party, led by Juha Sipilä, won the election by a significant margin. To be formed in collaboration with social partners to restore Finnish competitiveness and increase labour supply, the new social contract was the centrepiece of the new government's agenda. Once elected Sipilä started negotiations on this contract with labour market organisations. These negotiations ended in May 2015 without result. Unions considered the contract to be 'employer friendly' not least because it proposed extending working time by 100 hours per year, amounting to two and a half weeks extra work without compensation for their members (Jokinen, 2015). After this failure Sipilä stated that the burden facing the next government to cut from public finances would be even greater: 'We are talking about a total sum of ten billion Euros' (YLE, 7 May 2015a). This failure, moreover, prompted Sipilä to form a right wing coalition consisting of the National Coalition Party, the Centre Party and the populist Finns Party (YLE, 7 May 2015b). The Social Democratic Party, the Green League, the Left Alliance, the Swedish People's Party and Christian Democrats formed the opposition in the Parliament of Finland. 
The attempt by Sipilä to secure a new social contract was by no means the first time a Finnish government had attempted such a move. During the 1990s - when Finland was in a period of deep recession - the Centre Party Prime Minister Esko Aho aimed to build a social contract designed to reduce nominal wages and increase the competitiveness of the Finnish economy (Kiander, 2001). Aho's negotiation tactics failed because of irreconcilable differences between unions and industry. As a result, and by means of monetary policy, the government (for the last time) devalued the then Finnish currency, the mark. In so doing Finland trod a well-worn path. Indeed, prior to European Monetary Union (EMU) for countries where economic growth had stagnated a common strategy used to stimulate competitiveness was a devaluation of national currencies in relation to competitors. The external devaluation of the Finnish mark was, then, used as a policy measure to improve the competitiveness. Together with economists, Aho was discontent with this measure not least because, as he saw it, it did not offer a permanent solution to the problem of competitiveness. At the present juncture, that is, in the context of the European Monetary Union (EMU), such a strategy of external devaluation is, however, no longer possible (Blyth, 2013; Pochet, 1999; Saari, 2001). Indeed, in situations of economic stagnation or slow down the only fiscal option apparently open to countries such as Finland to improve the profitability of export businesses is an internal devaluation including wage reductions, the tightening of labour conditions and the reduction of employers' social security costs. That is, the only fiscal option open to countries locked into the EMU in a context of economic stagnation is a strategy of austerity.

It is important to recall here that the key instrument which opened the way for the Euro becoming the common currency for the EMU was the Treaty for European Union. In addition to enabling monetary union, the 1992 Maastricht Treaty limited an annual deficit of each member state to 3 per cent of GDP and public debt to 60 per cent. This was achieved by means of EU's Stability and Growth Pact (SGP) enacted in 1997, which set preventive and corrective rules and binding regulations for the Euro area concerning public finances and the coordination of fiscal policies. The infrastructural and institutional context of the present-day attempts to secure a social contract is then notably different from those of the 1990s. Not only is Finland now part of 
the EMU but portrays itself as a 'committed member' aiming to promote economic growth and competitiveness to these ends (Prime Minister's Office, 2015: 35). Indeed, the EMU context and the need to make 'necessary' structural reforms to cover a ten billion Euro 'sustainability gap' (or deficit), made agreement on a social contract (that is, internal devaluation) a pressing issue for the new government despite the failure of the earlier negotiations. As a consequence, the government embedded the social contract in its Strategic Programme published in May 2015. The programme stated:

By no later than 30 July 2015, the Government will make a proposal to social partners on measures (social contract) to reduce unit labour costs by at least 5\% [...]. Government expects social partners to commit comprehensively to a social contract by 21 August 2015. If social partners accept the Government's proposal, and the measures are clearly having an effect in March 2017, the Government will withdraw the conditional expenditure savings and tax increases it had decided. In addition, the Government is prepared to support the above-mentioned contract with significant income tax reductions. The net effect of the social contract and agreed pay settlements must strengthen the general government budgetary balance by at least half a percentage point of GDP at 2019, taking into account the tax reductions linked to them. (Prime Minister's Office, 2015: 14).

Notwithstanding the failure of earlier negotiations, the government therefore persisted with its expectation that social partners commit to its social contract. In so doing the government sought to actively re-calibrate the terms of the tripartite agreements that have characterized the post-war settlement in Finland. While under stress since before the 1990s (Kettunen, 2008; Kantola and Kananen, 2013), the tripartite agreements have, nonetheless, continued to play an important role in Finnish labour market and income policies. What surprised the social partners in this round of proposed reform, however, was the fast decision making process it involved with the government aiming to change the terms of collective agreements in just a few months. ${ }^{6}$ Partly due to this hastiness the social contract was not signed on the proposed 
deadline. Indeed, the situation prompted rifts between government and the trade union confederation as well as restlessness in the labour market.

After the negotiations on the contract failed the second time, the Prime Minister gave a televised national address urging unions to step into line. In the address Sipilä (2015b) stressed that while internal devaluation would not be a permanent reform, there is 'no real readiness for a joint agreement'. As a consequence, he proposed that the government would have no choice but to interfere in the freedom of contract via the use of legislation. Sipilä also set out how 'Ireland and Portugal have cut far more' and that if Finland does not embrace austerity it would no longer be the best student in the EU class but the next Greece (Sipilä, 2015b).

While the government urged unions to accept the terms of social contract in the name of securing a way back to national prosperity at the same time it attempted to focus the population's attention on technocratic measures of the problem at hand. This included both the public display of a debt clock and statements regarding the debt that the clock measured. In his televised address Sipilä, for example, declared that 'The Finnish state has contracted debt at a rate of almost a million Euros per hour for seven years, day and night, every day of the week' (Sipilä, 2015b). In this environment, what was clear was that via the new social contract unions were being asked not simply to accept the devaluation of the wages of their members but in so doing to take on responsibility for the nation's finances and especially its public debt. Indeed, unions were being commanded to reduce wages to enable the state to conform to the fiscal requirements of the SGP. Instead of empowered to negotiate the terms and conditions of labour contracts unions were being asked to impose financial austerity on their own members for the sake of the nation's finances. At issue, then, was not only the reform of the terms and conditions of collective agreements but also the indexing of wages to national debt and the requirements of the SGP.

\section{The Social Contract as a Competitiveness Pact}


By the fall of 2015 the social partners had withdrawn their co-operation as they could not reach agreement over the terms of the social contract. In response, the government threatened to bring intensified austerity measures and additional wage cuts through legal channels. Early in 2016, however, the central unions agreed to restart the negotiations not least because of the threat of the use of legislator's means to force the terms of the contract and cut labour costs by at least 5 per cent. Indeed, a tentative draft of a social contract, then renamed a Competitiveness Pact, was agreed on February by the central unions and employer's organizations. It was also agreed that central unions and employers' organizations would complete negotiations in each industry by the end of May 2016 to achieve amendments in their collective agreements. Despite initial disputes and struggles settlement was therefore achieved. This settlement should, in fact, be understood to be continuous with the history of Finnish tripartite agreements not least because all parties concurred on its primary goals: to improve the cost competitiveness of companies and, thereby, to reduce unemployment. Thus, and in line with previous amendments to the agreements, all parties shared a common rationality (Kantola and Seeck, 2011; Kettunen, 2008).

By September 2016 unions representing over 90 per cent of workers had signed the Pact. What accelerated the agreement process was a pledge on the part of government to make income tax reductions. In addition, for the social partners the pact was considered to be a better solution than dealing with compelling legislation. While legal means were not ultimately pursued, the latter nonetheless serves as a paradigmatic example of how the juridical brings form to the economic' (Foucault, 2008: 163) or how 'law becomes a medium for disseminating neoliberal rationality' (Brown, 2015: 151). Indeed, under the threat of legal means the following measures were agreed: annual working hours to be extended by 24 hours; public sector holiday bonuses to be reduced; the transfer of 2.05 percentage points of unemployment insurance and social security contributions from employers to employees; reductions for employers in health insurance contributions, and the adoption of a 'Finnish model' in regard to pay, that is, pay moderation amounting to wage freezes throughout 2016 and 2017 (Rehn, 2016). What is clear 
from these measures is that the Pact works to transfer wealth from employees to employers and risk from employers to employees.

Beyond issues of such transfer, critical for our concerns here is that the key actor in the forging of the agreements and arrangements with the social partners is the state. More precisely, the concrete actor is the state with its 'unusually detailed economic programme' constituted and mobilised because 'Finland, once Europe's economic wunderkind, is now in danger of becoming subject to the excessive deficit procedure and the budgetary supervision of Brussels' (Sipilä, 2015a). Collective agreements have, especially since the 1990s, been an important instrument in moderating pay increases with the stated aim of maintaining national competitiveness (Kuusisto, 2010). Social contracts in Finland have therefore not been neutral but involved the assertion of the interests of the state. However, prior to the European 2008 debt crisis, while mediated by the state, wage bargaining in Finland (as in other Nordic states) placed emphasis on labour market agents, that is, on social partners. Thus, the Nordic Model held that for wellfunctioning wage bargaining the negotiating parties of the labour market rather than the state have important roles to play' (Andersen et al., 2007: 28). What stands out in the Competitiveness Pact - in which national competitiveness is condensed to the devaluation of labour - is that it is the state, rather than labour market parties, which is playing the central role. Most significant for the purposes of this article, and contra to certain reflexes regarding neoliberal reform, is that the devaluation of wages is being set in motion not via a retreat of the state from agreements on the price and pricing of labour, or via the subordination of state power to that of the market, but via a state led set of institutional agreements.

The changing role of the state is also visible in the vocabulary regarding the notion of social contract. Prior to the debt crisis the welfare state was located as operating as a social contract for future generations which was under threat from globalization (Andersen et al., 2007: 13). In the current conjuncture, rather than acting as security against external threats, the social contract is positioned as a mechanism to deal with threats coming from within the welfare state, especially those connected to the wage-setting process, unit costs for labour, public 
sector costs and change-resistant citizens. In this sense, the new social contract might be understood as exemplary of what Brown (2015) has described as the inversion of the classic social contract. Here, rather than protected, individuals are legitimately sacrificed to the whole in order to maintain the productivity, growth, fiscal stability and credit rating of the nation. The indexing of wages to national debt and to the fiscal requirements of the EMU in order to restore price competitiveness may then be understood as a precise example of this inversion. It is also important to stress that in this inversion the state itself, including the operations of political power, does not remain the same.

This transformation of the state and political authority is particularly evident from an infrastructural point of view, indeed there are several points concerning infrastructural settings that are important to record here. One of these is that the groundwork for the employment and competitiveness section of the government's Strategic Programme was laid prior to the 2015 elections. Especially significant in this regard is the report $A$ Strategy for Finland (2015) which recommended that the government should task social partners with commencing negotiations on the reform of wage setting and especially to agree to the anchoring of the wage setting process in the demands of the competitive sector and to increase localized bargaining (Borg and Vartiainen, 2015: 29-36). One week before publication, Juhana Vartiainen, an economist and co-author of the report, announced he was to run as a parliamentary candidate for the National Coalition Party. Owing to these circumstances the report came under criticism for its purported political undertones. With direct reference to this controversy, in a press conference Borg (Vartiainen's co-author) stated 'the answers to the problems of Finland would be the same regardless of the moderate economist the country turned to' (Boxberg and Teivainen, 2015). This set of events not only makes clear how the scene for the eventual signing of the Competitiveness Pact was being set prior to the election of Sipilä, but also two aspects of the process of the economization of the political. First, it underscores a shift in political authority towards market experts, and especially to economists. Second, it highlights how this authority operates by virtue of visions of 'what works' (Brown, 2015; Davies, 2014), that is, by virtue of market based technical solutions to issues and problems that were previously firmly 
coded as political. Thus, in A Strategy for Finland (as well as in the social contract and Competitiveness Pact) wage setting is cast as a practical and technical question rather than a political issue concerning, for instance, collective agreements and public discussion.

Also significant in A Strategy for Finland was its emphasis on increasing local bargaining in regard to wages. This was by no means idiosyncratic, since the promotion of localized bargaining has been a long-term aim of Finnish business think tanks (Kantola and Kananen, 2013). Via the European Council, the European Commission has also recently recommended that Finland 'ensure that the wage setting system enhances local wage bargaining and removes rigidities, contributing to competitiveness and a more export industry-led approach' (European Council, 2016: 6). The Competitiveness Pact itself agreed that no special legislation be introduced to regulate local collective bargaining (and instead put in place a new national collective agreement: the Finnish model). Vartiainen, who insisted local bargaining and local wage setting was an important strategy to restore Finnish competitiveness, registered extreme frustration when this aim (also written into the broader government strategic programme) was - in his view - watered down in 'a humiliating manner' in negotiations regarding the Pact (Lepomäki and Vartiainen, 2016). The Competitiveness Pact does, however, take significant steps towards local bargaining not least because it contains 'significant elements towards firmlevel local agreement on working conditions' (Rehn, 2016), including working time and pay. The pact is, then, opening out the conditions and possibilities for localized agreements in regard to wages. What is significant about such bargaining is that while in the Nordic context this mechanism was previously understood as one whose use might achieve 'industrial peace' (Andersen et al., 2007: 24), the Pact unambiguously locates it as a mechanism through which wages (and the conditions of labour) can be calibrated in terms of post-national competition. In short, local bargaining enables further pressure to be placed on the unit price of labour.

What emerges from this picture of the Pact are a number of interrelated issues. First, (and most obviously) a devaluation of the price of labour; second the indexing and benchmarking of wages in terms of national debt and competitiveness; third, the economization of the political; and 
fourth, devolution. For our concerns, however, perhaps most significant is that an organized process of price devaluation is being set in motion via a set institutional agreements. Thus, rather than via the free play of the market or the setting loose from a set of institutional arrangements, the devaluation of wages is being achieved via a set of agreements between social partners, the state and quasi-state actors, agreements which are actively setting new terms for the price and pricing of labour and especially for what wages should be benchmarked against. Rather than via the Keynesian indexes of national inflation rates, the cost of living and the costs of the social reproduction of labour more generally these benchmarks include national debt (and its multiplier effects), the fiscal requirements of the SGP in regard to that very debt, and the (unquantifiable) requirements of post-national competition. Indeed, and inasmuch the Pact demands that citizens share sacrifice under macroeconomic imperatives (Brown 2015), it might be suggested that it also concerns the instantiation within the Finnish context of a depoliticized economy as well as an economized polity.

\section{Workfare as Orchestrated Devolution}

As set out above, the government's Strategic Programme seeks not only to secure a new social contract, but to continue welfare reform. This includes an intensification of and experiments with workfare, that is, with work-based welfare reform. The principles of the latter inhere around commands towards mandatory work activities for unemployed populations in the context of complex regimes of sanctioning. Workfare has been, and continues to be, central to the reform of welfare states, not least because workfare measures have typically been rolled out alongside centrally orchestrated devolutions of employment services (see especially Peck 2001). Workfare principles have been adopted in Finland for some time. A process of the devolution of the provision of employment services, for example, began after the 1990s recession in which Finland experienced high rates of unemployment (peaking at 17 per cent in 1993). Employment service provisioning has continued along this devolutionary path. In addition, Finland has adopted and adapted 'best practices' in regard to workfare from other OECD countries and more broadly employment policies have shifted firmly away from a focus 
on issues of demand toward issues of supply, that is, have followed a Schumpeterian path (Julkunen, 2013; Kananen, 2014)..$^{7}$ Of particular interest in the set of reforms that took place from the 1990s onwards is the conflicted financial situation they put in place between municipalities and the state. Two reforms are particularly significant in this regard: the 2001 Act on Rehabilitative Work Experience administered by the Ministry of Social Affairs and Health, and (from 2002) the promotion of Labour Force Centres for hard-to-employ clients, administered by the Ministry of Labour (Kananen, 2014; Keskitalo, 2008). These reforms not only gave over increasing responsibility for the provisioning of employment services to municipalities, but did so in a context of on-going funding cuts by the state to the municipalities themselves. In this respect these reforms are exemplary of a process identified by Brown (2015) as characteristic of neoliberal state reform, namely, the transfer of large-scale problems such as unemployment down the pipeline to small weak units in a context of the illusion of autonomy.

This process of devolution has a further level of complexity which is important to record here, namely the use of consultants to set the direction and content of policies. In the policy-making arena, since the 1980s Finland has adopted fashions in global management (Kantola and Seeck, 2011). In line with this trend, from the mid 2000s the state has increasingly contracted out policy making to consultants to the degree that Finland has been referred to as 'consultocracy' (Kuusela and Ylönen, 2013). Consultants and other 'non-political' actors were already used in the 1990 s when the preparation of the employment service reforms took place in two different but related settings: in high-level working groups which included representatives from political parties, social partners and other interest groups and in one- or two-person expert groups (Keskitalo, 2008). From this point onward a range of state and quasi-state actors began to provision employment services based on recommendations from consultants, think tanks, social partners and fiscal actors. This process of policy making via consultation is in direct view in the current government's reform of employment services where recommendations from a private consultant group - Owal Group Oy - take centre stage. 
Owal Group Oy was commissioned by the Ministry of Economic Affairs and Employment (TEM) to make a set of recommendations regarding the provision of employment services. As part of these recommendations, and drawing on existing models of employment services from nine OECD countries via peer review and benchmarking, in 2013-14 Owal Group Oy suggested that a 'shared vision and cooperation among public service, private employment services and service providers should be strengthened' (Oosi, 2014: 38). In an explicit demonstration of the operations of 'consultocracy', this recommendation appeared as one the key goals of the government's 2015 Strategic Programme. Indeed, this recommendation was set as one which would assist in the easing of labour market matching problems, the removal of deactivating measures, and ensuring the 'effective enforcement of the sanctions outlined in current legislation' (Prime Minister's Office, 2015: 16). To achieve this goal - which extends contractbased cooperation and purchasing from private service providers - the government has recommended a system of privately provisioned workfare programmes in which providers derive profits from meeting performance measures relating to the activities (including the labouring activities) of the unemployed.

Via its peer review and benchmarking exercise Owal Group Oy therefore became a key actor in the government's current programme of reform. Benchmarking is, however, by no means a neutral process. As a practice benchmarking dehistoricizes and decontextualizes via assumptions of transferability and interchangeability, that is, via assumptions that specific practices, principles and standards can be imported from one context and seamlessly reproduced in another. Moreover, as Brown (2015) has argued, benchmarking disseminates market values and economic metrics across space via best practice rhetoric. Benchmarking therefore facilitates the expansion of market principles into previously non-marketized spaces. These logics were made explicit by Owal Group Oy itself in their recommendations. Here, benchmarking was described as a non-academic practice which 'may not include all relevant details from different country systems' (Oosi, 2014: 9). Thus, disparate elements of employment service models from other OECD countries - such as the UK's model which gives for-profit service providers complete freedom in the organization of the services they deliver 
(Oosi, 2014: 56-57) - were used to develop a set of recommendations to reform Finnish employment service activities as if those models comprised transferable technical knowledge. ${ }^{8}$ When confronting workfare in contemporary Finland what emerges, then, is not only a picture of intensification and devolution over successive rounds of reform but also a further instantiation of the economization of the political via consultant led reform and the expansion of market principles. As we elaborate in the following section this includes the expansion of the principle of competition in regard to the price of labour into job services provision, that is, into workfare initiatives.

\section{Experimenting with the Unemployed: Work Demonstration}

As Peck (2001) has set out, workfare initiatives put pressure on the price of labour by provisioning a cheap supply of labour to flexible labour markets and do so via the system of sanctions they operate in regard to welfare payments. Workfare must then be understood as a state intervention that scaffolds the operations of flexible labour markets. In the current round of reform of Finnish workfare the relationship between workfare and the pricing of labour has, however, taken a distinctive turn. To understand this turn it is important to make clear that across its Strategic Programme the Finnish government seeks to promote what it has termed a culture of experimentation, that is, a culture which seeks to find 'innovative solutions, promote individual initiative, and strengthen local decision-making' (Prime Minister's Office, 2015: 28). In its Strategic Programme the government set out how workfare initiatives should themselves take place within such an experimental culture. As part of the current round of employment services reform, for example, a new workfare initiative - or workfare experiment - termed work demonstration has been introduced. Announced by the Minister of Justice and Minister of Labor, Jari Lindström (Lindström, 2016), and launched in late 2016, in this experiment those enrolled in workfare schemes have been permitted to demonstrate their working skills to employers without salary or contract via direct requests to employers. This experiment therefore gives license to the unemployed - under the banners of 'individual initiative', 'innovative solutions' and 'local decisions' - to demonstrate their skills speculatively to 
potential employers in the hope that such demonstrations will convert into waged labour. Such demonstrations, moreover, take place via the initiative of the unemployed themselves.

Work demonstration is in fact built on a model designed by the Finnish Innovation Fund Sitra, which can be considered a state think tank (Ahlqvist and Moisio, 2014). Sitra's task has been to promote Finland's stable and balanced development, economic growth and international competitiveness. Sitra is, then, a key part of a state infrastructure which - via economic expertise - promotes competitiveness. Like many other competitiveness institutions Sitra produces and promotes the use of experimental models to deal with complex problems (such as unemployment) in ways which position the proposed experiments as scientific, objective, future orientated and solution focused. The opening out of competition and competitiveness to which such models are attuned is therefore presented as a scientific and objective venture rather than as the promotion of the principle of competition.

After public discussion about work demonstration Sitra defended their experimental workfare model in a blog post. Written by two Sitra experts the post made clear that the model was grounded in the findings of a project on which the experts had both worked: 'Transformation of Working Life'. This project surveyed the attitude of Finnish people to the future of work including what they would be prepared to sacrifice if the chips were down. According to the experts, almost 19 per cent of respondents to the survey stated that they would be prepared to work without salary if it would help them find a job. In addition, 19 per cent responded that they were 'quite sure' they would do so (Hyttinen and Kesä, 2016). Given that the work demonstration model was built around these and similar findings from the survey what is clear is that strong moral imperatives are embedded in this initiative. Thus, work demonstration assumes that would-be waged workers will sacrifice salaries in their quest for waged-work. What is clear, in other words, is how work demonstration - like other workfare initiatives (Peck, 2001) - seeks not only to activate the working capacities of unemployed populations but also to generate a distinct moral economy in regard to work and working based on sacrifice and deferral. 
What is of particular interest concerning work demonstration, however, is how it contributes to - and in fact accelerates - the process of internal devaluation in regard to wages being sought by the government in the current round of reform. Although there is no statistical evidence available yet whether work demonstration has led to wage devaluation, it is noteworthy that work demonstration is explicitly designed to achieve such devaluation on a micro scale since it aims to set in play a face-to face-competition in regard to wages between those enrolled in workfare schemes and those in employment. Thus, this experiment is designed to unfold a process of competition in regard wages whereby as part of demonstrating their skills to potential employers, the unemployed are expected to offer their labour at rates which undercut those of existing employees. Work demonstration therefore opens out state backed contestations between the employed and unemployed in regard to the price of labour on a one-to-one scale. This experiment should then be understood as one designed to contest and produce volatility in the price and pricing of labour on a micro scale. Such contestations, moreover, take place under the banner of the promotion of 'individual initiative', 'innovative solutions' and 'local decisions'. It is, then, not only through the Competitiveness Pact that the government is seeking to achieve internal devaluation in regard to the price of labour but also via experiments in workfare. These experiments not only push large scale problems down the line, but do so to such a degree that individuals themselves now put in play competition in regard to wages as part of the solution to what has become their very own problem: unemployment.

\section{Conclusion}

In this article, by focusing on specific aspects of the current Finnish government's reform programme, we have highlighted a process of the organized devaluation of the price of labour. Via our analysis of the Competitiveness Pact and the on-going reform of the welfare state we have shown how this process of devaluation involves a variety of actors - including economic and fiscal - operating on a range of scales and how competition in regard to the price of labour 
is being achieved via a set of dispersed mechanisms. The latter include agreements with social partners, agreements on public debt thresholds and experiments with workfare. In forwarding this analysis one of our aims has been to highlight how rather than an outcome of deregulation and the free play of the market, competition in regard to the price of labour is being achieved via a set of co-ordinating mechanisms in which the state - albeit a transformed state - plays a key role. This article therefore cautions against an understanding of the emergence of competition in regard to price as part of a process of the subordination of the power of the state to the market and especially to market based competition and market based actors. Indeed, this article highlights how competition in regard to the price of labour is in large part state designed. We would suggest therefore that the actions of the state should form a focus of any contemporary sociology of price and pricing and especially of competition in regard to price.

In making explicit the process of the organized devaluation of the price of labour we have also, however, necessarily confronted the transformation of the state itself and especially the economization of the political along two axes. First, a shift in political authority towards market experts including consultants and economists. Second, the expansion of market based technical solutions to problems previously coded as issues of public and political concern. The analysis we have set out here has shown how the economization of the political along these lines runs rife in the current round of reform and is central to the emergence of a state formation whose purpose is to facilitate competition. Indeed, following Brown (2015), we have suggested that this process is central to the inversion of the classic social contract which the current round of reforms is explicitly putting in play. Thus, current reform commands Finnish citizens to give up forms of state protection (for instance in regard to wages) and sacrifice themselves to the whole in order to maintain the productivity, growth, fiscal stability, credit rating and competitiveness of nation. Confronting the organized devaluation of the price of labour therefore entails coming face to face not only with the on-going reform of the state but also with the turning inside out of the social contract. 


\section{Sources}

Andersen T M, Holmström B, Honkapohja S, Korkman S, Söderström H T and Vartiainen J (2007) The Nordic Model: Embracing Globalization and Sharing Risks. Helsinki: The Research Institute of the Finnish Economy.

Borg A and Vartiainen J (2015) Strategia Suomelle. Helsinki: Prime Minister's Office.

Boxberg K and Teivainen A (2015) Borg calls for strict wage moderation. Helsinki Times March 15. Available (consulted 12 May 2017) at: http://www.helsinkitimes.fi/finland/finlandnews/politics/13280-borg-calls-for-strict-wage-moderation.html

European Council (2016) Recommendation for a Council: Recommendation on the 2016 National Reform Programme of Finland and Delivering a Council Opinion on the 2016 Stability Programme of Finland. Brussels: European Commission.

Hyttinen M and Kesä M (2016) Työnäyte parantaisi työttömän asemaa. Sitra April 13. Available (consulted 12 May 2017) at: http://www.sitra.fi/blogi/tyoelaman-taitekohdat/tyonayteparantaisi-tyottoman-asemaa-tyonhakijana

Jokinen H (2015) Plan for a social contract for labour market fails. Akava May 11. Available (consulted 12 May 2017) at:

http://www.akava.fi/en/current issues/plan for a social contract for labour market fails.1 4909.news

Lepomäki E and Vartiainen J (2016) Kilpailukykysopimus vaarantaa uudistukset. Helsingin Sanomat March 30. Available (consulted 12 May 2017) at:

http://www.hs.fi/paakirjoitukset/a1459225322001 
Lindström J (2016) Työllisyyspaketti. Ministry of Economic Affairs and Employment April 12. Available (consulted 12 May 2017) at:

http://www.slideshare.net/TEM esitykset/ministeri-lindstrmin-esitys-tyllisyyspaketista

Oosi O (2014) International Peer Review of Labour Policy Service Structures. Helsinki: Ministry of Economic Affairs and Employment.

Prime Minister's Office (2015) Finland, a Land of Solutions: Strategic Programme of Prime Minister Juha Sipilä’s Government. Helsinki: Government Publications.

Rehn O (2016) Competitiveness and sustainable growth: Reforming the Finnish economy. Ministry of Economic Affairs and Employment September 6. Available (consulted 12 May 2017) at: http://tem.fi/en/article/-/asset publisher/competitiveness-and-sustainable-growthreforming-the-finnish-economy

Sipilä J (2015a) Prime Minister Juha Sipilä's speech in Parliament on the Strategic Government Programme. Government Communications Department June 2. Available (consulted 12 May 2017) at: http://valtioneuvosto.fi/artikkeli/-/asset publisher/10616/paaministeri-juha-sipilastrategisen-hallitusohjelman-tiedonantokeskustelussa-eduskunnassa-2-62015? 101 INSTANCE 3wysILo1Z0ni languageld=en US

Sipilä J (2015b) Prime Minister Juha Sipilä's speech on the Finnish Broadcasting Company YLE on 16 September 2015. Government Communications Department September 16. Available (consulted 12 May 2017) at:

http://valtioneuvosto.fi/en/artikkeli/-/asset_publisher/paaministeri-juha-sipilan-puhe-ylen-tv1kanavalla-16-9-2015? 101 INSTANCE 3wys|Lo1Z0ni groupld=10616

YLE News (2015a) Sipilä's 'Social Contract' with labour reps comes up dry. YLE News May 7. Available (consulted 12 May 2017) at: 
http://yle.fi/uutiset/osasto/news/sipilas social contract with labour reps comes up dry/79 $\underline{78395}$

YLE News (2015b) Sipilä opts for right-leaning government. YLE News May 7. Available (consulted 12 May 2017) at: http://yle.fi/uutiset/osasto/news/sipila opts for rightleaning government/7979421

\section{References}

Adkins, L (2017) Disobedient workers, the law and the making of unemployment markets, Sociology 51(2) (2017): 290-305.

Ahlqvist T and Moisio S (2014) Neoliberalisation in a Nordic state: From cartel polity towards a corporate polity in Finland. New Political Economy 19(1): 21-55.

Alasuutari P (2016) The Synchronization of National Policies: Ethnography of the Global Tribe of Moderns. London: Routledge.

Blyth M (2013) Austerity: The History of a Dangerous Idea. Oxford: Oxford University Press.

Brown W (2015) Undoing the Demos: Neoliberalism's Stealth Revolution. New York: Zone Books.

Bourdieu P (1998) Acts of Resistance: Against the New Myths of our Time. Cambridge: Polity.

Bourdieu P (2003) Firing Back: Against the Tyranny of the Market 2. London: Verso.

Chomsky N (1999) Profit Over People: Neoliberalism and the Global Order. New York, NY: Seven Stories Press. 
Davies W (2014) The Limits of Neoliberalism: Authority, Sovereignty and the Logic of Competition. London: Sage.

Elomäki A, Kantola J, Koivunen A and Ylöstalo H (2016) Kamppailu tasa-arvosta: tunne, asiantuntijuus ja vastarinta strategisessa valtiossa [A battle about gender equality: Affect, expertise and resistance in the strategic state]. Sosiologia 53 (4): 377-395.

Foucault M (2008) The Birth of Biopolitics. Basingstoke: Palgrave Macmillan.

Harvey D (2007) A Brief History of Neoliberalism. Oxford: Oxford University Press.

Harvey D (2010) The Enigma of Capital and the Crises of Capitalism. London: Prime Books.

Heiskala R and Kantola A (2010) Vallan uudet ideat: hyvinvointivaltion huomasta valmentajavaltion valvontaan [The power of new ideas and new ideas about power: From the caring lap of the welfare state to the surveillance of the coaching state]. In: Pietikäinen P (ed) Valta Suomessa [Power in Finland]. Helsinki: Gaudeamus, 124-148.

Humphrys E and Cahill D (2017) How labour made neoliberalism. Critical Sociology 43(4-5): 669684.

Jessop B (2002) The Future of the Capitalist State. Cambridge: Polity.

Julkunen R (2013) Aktivointipolitiikka hyvinvointivaltion paradigman muutoksena [Activation policy as a welfare state paradigm change]. In: Karjalainen $\mathrm{V}$ and Keskitalo E (eds) Kaikki työuralle! - Työttömien aktiivipolitiikkaa Suomessa [Activation Policy in Finland]. Helsinki: THL, 21-44. 
Kananen J (2014) The Nordic Welfare State in Three Eras. From Emancipation to Discipline. London: Routledge.

Kantola A and Kananen J (2013) Seize the moment: Financial crisis and the making of the Finnish competition state. New Political Economy 18(6): 811-826.

Kantola A and Seeck H (2011) Dissemination of management into politics: Michael Porter and the political uses of management consulting. Management Learning 42(1): 25-47.

Kauppinen T (2005) Suomen työmarkkinamalli [Finland's labour market model]. Helsinki: WSOY.

Keskitalo E (2008) Balancing Social Citizenship and New Paternalism: Finnish Activation Policy and Street-level Practice in a Comparative Perspective. Helsinki: Stakes.

Kettunen P (2008) Globalisaatio ja kansallinen me. Kansallisen katseen historiallinen kritiikki [Globalization and the National We: A Historical Critique of the National Gaze]. Tampere: Vastapaino.

Kiander J (2001) Laman opetukset. Suomen 1990-Iuvun kriisin syyt ja seuraukset [Lessons from the Recession. The Causes and Results of the 1990s Economic Crisis in Finland]. Helsinki: Government Institute for Economic Research.

Konings M (2010) Rethinking neoliberalism and the crisis: Beyond the re-regulation agenda. In: Konings M (ed) The Great Credit Crash. London: Verso, 3-30.

Kuusela H and Ylönen M (2013) Konsulttidemokratia. Miten valtiosta tehdään tyhmä ja tehoton [Consultocracy. How the State is Made Foolish and Ineffective]. Helsinki: Gaudeamus. 
Kuusisto A (2010) Finland - Four decades of incomes policy agreements coming to an end? In: Pochet P, Keune M and Natali D (eds) After the Euro and Enlargement: Social Pacts in the EU. Brussels: European Trade Union Institute, 223-250.

Mirowski P (2009) Postface: Defining neoliberalism. In: Mirowski P and Plehwe D (eds) The Road from Mont Pèlerin: The Making of the Neoliberal Thought Collective. Cambridge: Harvard University Press, 417-455.

Mirowski P and Plehwe D (eds) (2009) The Road from Mont Pèlerin: The Making of the Neoliberal Thought Collective. Cambridge: Harvard University Press.

Mykkänen J (2016) Strategic Government Program: Overview of the Procedure and Its Execution. Helsinki: Economic Policy Council.

Peck J (2001) Workfare States. New York: Guilford Publications.

Peck J and Theodore N (2015) Fast Policy: Experimental Statecraft at the Thresholds of Neoliberalism. Minneapolis: University of Minnesota Press.

Peck J, Theodore N and Brenner N (2018) Actually existing neoliberalism. In: Cahill D, Konings M, Cooper M and Primrose D (eds) The Sage Handbook of Neoliberalism. London: Sage.

Plehwe D (2009) Introduction. In: Mirowski P and Plehwe D (eds) The Road from Mont Pèlerin: The Making of the Neoliberal Thought Collective. Cambridge: Harvard University Press, 1-42.

Pochet P (1999) Monetary Union and collective bargaining in Finland. In: Pochet P (ed) Monetary Union and Collective Bargaining in Europe. Brussels: Peter Lang, 219-244.

Saari J (2001) Bridging the gap: Financing of social policy in Finland 1990-1998. In: Kalela J, Loikkanen H, Simpura J, Kivikuru U and Kiander J (eds) Down from the Heavens, Up from the 
Ashes: The Finnish Economic Crisis of the 1990s in the Light of Economic and Social Research. Helsinki: Government Institute for Economic Research, 189-214.

Simone A (2012) Infrastructure: Introductory Commentary by Abdou Maliq Simone. Cultural Anthropology Curated Collections, November 26. Available (consulted 12 May 2017) at: https://culanth.org/curated collections/11-infrastructure/discussions/12-infrastructureintroductory-commentary-by-abdoumaliq-simone

\section{Notes}

${ }^{1}$ Cuts to public expenditures are by no means new in Finland. Following a severe financial crisis in the early 1990s successive Finnish governments began to dismantle the Nordic welfare state: ideas of redistribution and social insurance gave way to ideas about competitiveness (Heiskala and Kantola, 2010; Kantola and Kananen, 2013). During this period the Finnish state was reconfigured as a competition state. This reconfiguration was, however, not driven by an austerity agenda.

${ }^{2}$ Our focus in this article on the price and pricing of labour breaks with analyses which foreground wage suppression and wage stagnation in the context of neoliberal reform (see e.g. Harvey, 2007; 2010). As we will go on to demonstrate, attention to price and pricing makes explicit a number of processes at stake in the devaluation of wages which a focus on stagnation and suppression obscures, including the economization of the political. While price and pricing have conventionally not fallen with the remit of sociology, our suggestion therefore is that such a focus is both productive and necessary.

${ }^{3}$ The philosopher and historian of economic thought Philip Mirowski (see e.g. Mirowski, 2009) has drawn attention to the manner in which a number of left intellectuals - including Bourdieu and Harvey - mistake neoliberalism for a project that disempowers the state. In tune with the intervention we set out here, Mirowski makes explicit how the project of neoliberalism empowers the state and redefines its nature and functions (see also Davies, 2014).

${ }^{4}$ We recognize that neoliberalism is plural in practice (Plehwe, 2009). Via our focus on the current round of reform in Finland our intention in that this article contributes to empirical knowledge regarding such practice or, as Peck, Brenner and Theodore (2018) term it, actually existing neoliberalism.

${ }^{5}$ In this regard we recognize that policymaking is never only a domestic affair, indeed that contemporary policy making is relationally interconnected across time and space (Peck and Theodore, 2015; Alasuutari, 2016).

${ }^{6}$ On fast policy as paradigmatic of neoliberal reform see Peck and Theodore (2015). 
${ }^{7}$ Schumpeterian employment policies were adopted across OECD countries form the late 1970s onwards and aimed at securing employability and enhancing the competitiveness of open economies (Jessop, 2002). Such policies not only shifted away from Keynesian concerns with demand towards issues of labour supply but also located unemployment as a problem of competitiveness and especially as a problem of the competitiveness of labour.

${ }^{8}$ See Adkins (2017) on the UK model. 